ENTREPRENEURSHIP AND SUSTAINABILITY ISSUES

ISSN 2345-0282 (online) http://jssidoi.org/jesi/

2020 Volume 8 Number 2 (December)

http://doi.org/10.9770/jesi.2020.8.2(64)
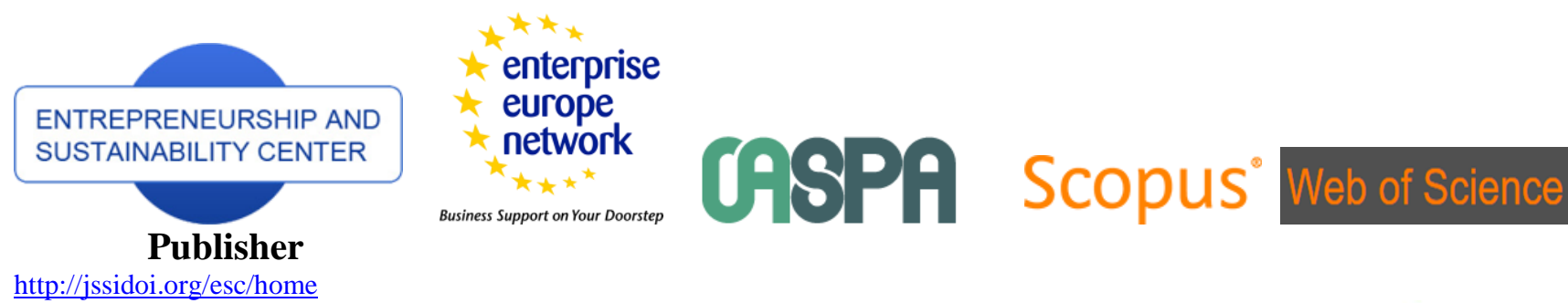

http://jssidoi.org/esc/home

\title{
DESIGN AND EVALUATION OF EFFICIENCY OF MACRO - LOGISTIC SYSTEMS FOR COUNTRIES WITH DEVELOPING ECONOMY
}

\author{
Yerlan Kunyazov ${ }^{1}$, Yertargyn Shakhman ${ }^{2}$, Saule Rakhimova ${ }^{3}$, Alma Mussina ${ }^{4}$, Takhir Ernazarov ${ }^{5}$ \\ 1,2,3,4,5 S. Toraighyrov Pavlodar State University, Lomov 64 street, Pavlodar, Kazakhstan \\ E-mails:l'kunyazov.erlan@mail.ru ; ${ }^{2}$ Shakhman2015@mail.ru; \\ ${ }^{3}$ saulesha_rahimova@mail.ru; ${ }^{4}$ alma1404@yandex.kz; ${ }^{5}$ denat_et@mail.ru
}

Received 18 December 2019; accepted 12 October 2020; published 30 December 2020

\begin{abstract}
In modern conditions, improving the efficiency of logistics is of particular importance, especially for countries with developing economies. The development of logistics acts as a driver of the competitiveness of the country's economy, improving the quality of life of the population, and rational integration into the world economy. Therefore, the states of countries with developing economies face the global task of becoming a certain transit and logistics hub of the region, a "bridge" between Europe and Asia, the implementation of which directly depends on the development of transport logistics, the main factor in stimulating sustainable rates of industrial growth and the formation of competitive advantages of the economic system. The toolkit developed by the author and the results obtained can be used by state and local authorities in the development of strategies for the development of macrological systems in countries with developing economies for the medium term.
\end{abstract}

Keywords: logistics; macro-logistic systems; material and intangible logistics flows; logistics infrastructure; the mechanism of functioning of the macro-logistic system

Reference to this paper should be made as follows: Kunyazov, Ye., Shakhman, Ye., Rakhimova, S., Mussina, A., Ernazarov, T. 2020. Design and evaluation of efficiency of macrologistic systems for countries with developing economy. Entrepreneurship and Sustainability Issues, 8(2), 1062-1082. http://doi.org/10.9770/jesi.2020.8.2(64)

JEL Classifications: $\mathrm{O} 18, \mathrm{O} 14$

\section{Introduction}

Analysis of the state and development trends of logistics in the world economy shows that in many respects the state of logistics and supply chain management (SCM) is a key factor in increasing the competitiveness potential. The global economic crisis, which over the past decades, has clearly demonstrated how important is the ability of macrologistic systems not only to reduce costs, but also to find new innovative solutions to maintain business stability in difficult and poorly predictable macroeconomic conditions. Those systems that were able to correctly assess the situation and reorganize in time to new rails of integration and coordination, both of internal logistics 


\section{ENTREPRENEURSHIP AND SUSTAINABILITY ISSUES}

ISSN 2345-0282 (online) http://jssidoi.org/jesi/

2020 Volume 8 Number 2 (December)

http://doi.org/10.9770/jesi.2020.8.2(64)

Make your research more visible, join the Twitter account of ENTREPRENEURSHIP AND SUSTAINABILITY ISSUES: @Entrepr69728810

business processes and relationships with counterparties in supply chains, were able not only to maintain their positions, but also to achieve significant results in increasing competitiveness and strengthening market positions. In a modern economy, the use of the principles of integrated logistics is one of the basic sources of sustainable competitive advantage for logistics systems. That is why the world's leading companies are making significant efforts to improve the efficiency of supply chains, focusing on the active involvement of logistics providers, the globalization of the location of production and logistics facilities and the implementation of the principles of integrating logistics business processes in building a business.

An effective logistics system is capable of speeding up the industrialization of the country through convergence within industrial centers, as well as creating a basis for deepening regional and Eurasian economic cooperation and further integration of countries into the world economy. Moreover, the strategically advantageous geographic location of the country allows you to receive a significant source of income through the active implementation of transit opportunities.

The intensive development of the logistics services market, the creation of a competitive environment in the field of commodity circulation and international transportation of goods, the strengthening of integration trends in the world economy make it necessary to search for adequate market mechanisms to ensure the effective functioning of the transport complex, which are considered logistics and logistics management. Hence follows the high urgency of solving problems aimed at the development of transport and logistics infrastructure, in particular, at the formation of transport and logistics hubs, as an integral and key component that ensures an increase in the efficiency of the transport complex. In the Kazakh economy, as in a country with a developing economy, logistics is a fairly young industry and, following the example of foreign countries, is only turning into a practical tool for a market economy.

\section{Research background}

To position and use the best practices of leading companies and countries in the field of logistics, special analytical tools are needed, in particular international ratings, which have become a source of information for analytics.

The analysis of approaches and ratings of logistics efficiency assessment at the country level existing in the world practice is presented in separate publications of such authors as V.I.Sergeev, D.I. Zinina (2016), A.P. Dolgov $(2015,2016)$, and others.

Professor A.P. Dolgov (2016), who studies the problems of assessing logistics in international rankings, identifies the following key points of a methodological nature:

- selection of a set of indicators that most fully characterize the evaluated phenomenon or process;

- the choice of a rational ratio between objective indicators and subjective assessments of quality characteristics;

- determination of weight coefficients characterizing the significance of certain particular indicators, estimates.

Until now, no single, well-established definition of the logistics system has been formed. According to E. Yu. Alekseycheva (2015), quite often in the economic literature there is a definition according to which a logistic system is understood as an adaptive system with feedback, which performs certain logistic operations and functions. Moreover, such a system consists of several subsystems, has developed connections with the external environment. In addition, there is another definition of V.V. Gabbasova (2016), who claims that the logistics system is a system for managing logistics processes that have feedback. These processes operate in a single multilevel structure, with a single center for the distribution of resources according to established criteria for the effectiveness of their use. This means that the system makes it possible to ensure the implementation of logistics 


\section{ENTREPRENEURSHIP AND SUSTAINABILITY ISSUES}

ISSN 2345-0282 (online) http://jssidoi.org/jesi/ 2020 Volume 8 Number 2 (December)

http://doi.org/10.9770/jesi.2020.8.2(64)

Make your research more visible, join the Twitter account of ENTREPRENEURSHIP AND SUSTAINABILITY ISSUES: @Entrepr69728810

operations with optimal costs for moving products throughout the supply chain. Therefore, an enterprise that has organized a logistics service is able to effectively solve problems associated with reducing costs, distributing and storing products, and reducing inventories. The saved costs allow to reduce the production cost. Some researchers, such as O.S. Damdyn (2015) notes that transport logistics is understood as the organization of functioning and management of material flows, as well as the corresponding supporting and accompanying flows in the process of goods movement. Other scholars, like B. Galstyan (2018), give a broader definition of the term. They emphasize that transport logistics is the movement of products by vehicles using a specific technology, specific routes in the supply chain. Such logistics consists of logistic, technological operations and functions. At the same time, it includes forwarding, cargo handling, packaging, transfer of ownership of the cargo, prevention of threats, insurance of risks, customs procedures, etc.

Analysis of the points of view of foreign authors made it possible to single out three definitions of the logistics infrastructure:

- according to D. Greenwald (1973) - this is a set of service industries, the list of which varies depending on the object and the operational composition of the activities of service subjects;

- W. Stanton (1978) claims that this is a set of material and technical means that provide normal conditions for the activities of economic entities;

- research of W. Rostow (1960) They agree that this is a set of conditions that create favorable preconditions for the development of commodity circulation in industries that meet the needs of the population.

According to A.M. Gadzhinsky (2018), the specificity of logistics consists in the allocation of a single function of management of previously disparate material flows; in the technical, technological, economic and methodological integration of individual links of the material-conducting chain into a single system that ensures effective management of end-to-end material flows.

Well-known approaches to assessing and predicting the effectiveness of logistics systems under given conditions, set forth in the works of the following domestic and foreign researchers (Table 1).

Table 1. Approaches to assessing and predicting the effectiveness of logistics systems in given conditions

\begin{tabular}{|l|l|}
\hline \multicolumn{1}{|c|}{ Author } & \multicolumn{1}{|c|}{ Approaches to assessing and predicting the effectiveness of logistics systems } \\
\hline Anikin B. (2016) & $\begin{array}{l}\text { Criteria for the level of service in logistics are stated, where two areas of global importance are } \\
\text { considered, associated with global logistics and logistics of "slender" production, as well as the } \\
\text { problem of integrating organizations into the global logistics network }\end{array}$ \\
\hline Gutthorna J. (2018) & $\begin{array}{l}\text { Shows production and logistics activities in a smooth integration into supply chains of key } \\
\text { business processes: production, distribution, transportation, forecasting and planning of demand, } \\
\text { inventory management, service management and supply of spare parts, controlling and } \\
\text { management of return material flows }\end{array}$ \\
\hline Dolgov A. (2015) & $\begin{array}{l}\text { The modern economic problems of regulation of flow processes and inventories in macrologistic } \\
\text { systems of various hierarchical levels are considered }\end{array}$ \\
\hline Dybskaya B. (2015) & $\begin{array}{l}\text { A detailed analysis of the logistics process in a warehouse based on functional modeling is } \\
\text { given. Specific recommendations for practitioners on the effective design and use of warehouse } \\
\text { systems, optimization of the choice of technological and handling equipment for warehouses, } \\
\text { planning of warehouse areas and other urgent problems of warehousing logistics are given }\end{array}$ \\
\hline Kurenkov P. (2016) & $\begin{array}{l}\text { The research focuses on warehouses in logistics, which perform the function of accumulating } \\
\text { reserves, which are necessary to mitigate and damp fluctuations in the volume of demand and } \\
\text { supply, thereby allowing the use of these resources in the event of a shortage of products on the } \\
\text { market }\end{array}$ \\
\hline Levkin G. (2019) & $\begin{array}{l}\text { A comprehensive understanding of the features of material flow management in industry and } \\
\text { trade is considered }\end{array}$ \\
\hline Shulzhenko T. et al. (2017) & The classification of models and methods used in the theory of logistics is considered; analyzed \\
\hline
\end{tabular}




\section{ENTREPRENEURSHIP AND SUSTAINABILITY ISSUES}

ISSN 2345-0282 (online) http://jssidoi.org/jesi/ 2020 Volume 8 Number 2 (December)

http://doi.org/10.9770/jesi.2020.8.2(64)

Make your research more visible, join the Twitter account of ENTREPRENEURSHIP AND SUSTAINABILITY ISSUES: @Entrepr69728810

\begin{tabular}{|c|c|}
\hline & e most famous approaches used in procurement, production and distribution logistics \\
\hline Mirotin L., Levin, B. (2015) & $\begin{array}{l}\text { The issues of innovative processes in the field of transport management are considered, such as } \\
\text { trends in the development of the transport industry and the development of concepts, models and } \\
\text { mechanisms of logistics management of an intelligent transport system }\end{array}$ \\
\hline Myasnikova L. (2016) & $\begin{array}{l}\text { Examines modern problems of logistics management as the most important tool for increasing } \\
\text { the competitiveness of companies in the market }\end{array}$ \\
\hline $\begin{array}{l}\text { Prokofieva T., Lopatkin O. } \\
(2017)\end{array}$ & $\begin{array}{l}\text { The problems of formation and development of regional logistics transport and distribution } \\
\text { systems are investigated }\end{array}$ \\
\hline Sergeev V., Zinina D. (2016) & $\begin{array}{l}\text { Analysis of the approaches and ratings of logistics efficiency assessment at the country level } \\
\text { existing in the world practice. It is shown that the objectivity of assessing the effectiveness of } \\
\text { logistics can be increased using regression models that reveal the relationship between } \\
\text { macroeconomic indicators and the level of development of logistics in a particular country. The } \\
\text { proposed models help to minimize the impact of subjective expert assessments on the final } \\
\text { ratings }\end{array}$ \\
\hline $\begin{array}{l}\text { Scherbakov B. (2018), Jiao et } \\
\text { al. (2019); Adeniran, A.O., } \\
\text { Obembe, O.E. (2020); Mader } \\
\text { Michelle, M., Suski Cássio, } \\
\text { A. (2019) }\end{array}$ & $\begin{array}{l}\text { Shows a view of logistics as a field of entrepreneurial activity in the management of material, } \\
\text { information, financial and other flows. Covers the basic concepts of logistics, substantiates the } \\
\text { functional unity and efficiency of logistics solutions }\end{array}$ \\
\hline
\end{tabular}

Thus, in the development of the transport and logistics system, an important place is occupied by the formation of a logistics infrastructure, regarding the essence and content of which there are different points of view and components of the infrastructure of logistics processes. Investigating the management of integrated logistics systems in the digital economy, N.A. Gvilia, A.V. Parfenov, T.G. Shulzhenko (2019) established a relationship between the level of logistic integration and the form of intercorporate logistic formations, which made it possible to select management tools for certain forms of intercorporate logistic formations, including those based on the use of digital technologies. In the work of M. Adamczak, R. Domanski, L. Hadas, P. Cyplik (2016) aspects of the formation of integration relationships between production and logistics systems and elements of the external environment are considered. O. Mortansen, O. Lemoine (2008) investigates the system integration relationships between manufacturing enterprises and 3PL logistics providers.

Questions about measuring the strength of integration relationships between elements of intersystem logistics education are considered in the works of P. Cyplic, L. Hadas, M. Adamczak, R. Domanski, M. Kupczyk, Z. Pruska (2014), where an approach to measuring the level of integration in supply chains is proposed based on the ranking of local levels of integration in the implementation of integration processes in the supply chain.

At the same time, the development of digital technologies is of great importance, including in the management of logistics activities, which makes it possible to form tools for increasing the efficiency of the activities of both individual entities and the intersystem entities formed by them. In his scientific works, Y. Kayikci (2018) just describes the depth of interorganizational logistic integration, which is determined by the form of intercorporate interaction.

C. Wong, S. Boonitt, C. Wong (2011) investigated the principles of information integration of elements in supply chains, which make it possible to assert that for the forms of interorganizational interaction, estimates can be made that characterize the levels of logistic integration, which will differ significantly. V. Lukinskiya, V. Lukinskiya, T. Shulzhenko, T. (2017) describes logistic systems that are formed with the help of various types of logistic integration, which are considered as a combination of activities, complex implementation of functions and management influences, interaction of participants in the process. 
ENTREPRENEURSHIP AND SUSTAINABILITY ISSUES

ISSN 2345-0282 (online) http://jssidoi.org/jesi/

2020 Volume 8 Number 2 (December)

http://doi.org/10.9770/jesi.2020.8.2(64)

Make your research more visible, join the Twitter account of ENTREPRENEURSHIP AND SUSTAINABILITY ISSUES: @Entrepr69728810

Cluster forms of the logistic system, which are reflected in the works of L. Rivera, Y.Sheffi, D. Knoppen (2016) have been studied more deeply.

Thus, in the development of the transport and logistics system, an important place is occupied by the formation of a logistics infrastructure, regarding the essence and content of which there are different points of view and components of the infrastructure of logistics processes.

\section{Research questions}

To assess the effectiveness of macrological systems for countries with emerging economies, authors had determined the rating of the EAEU member states by logistics efficiency sub-indices among the CIS countries.

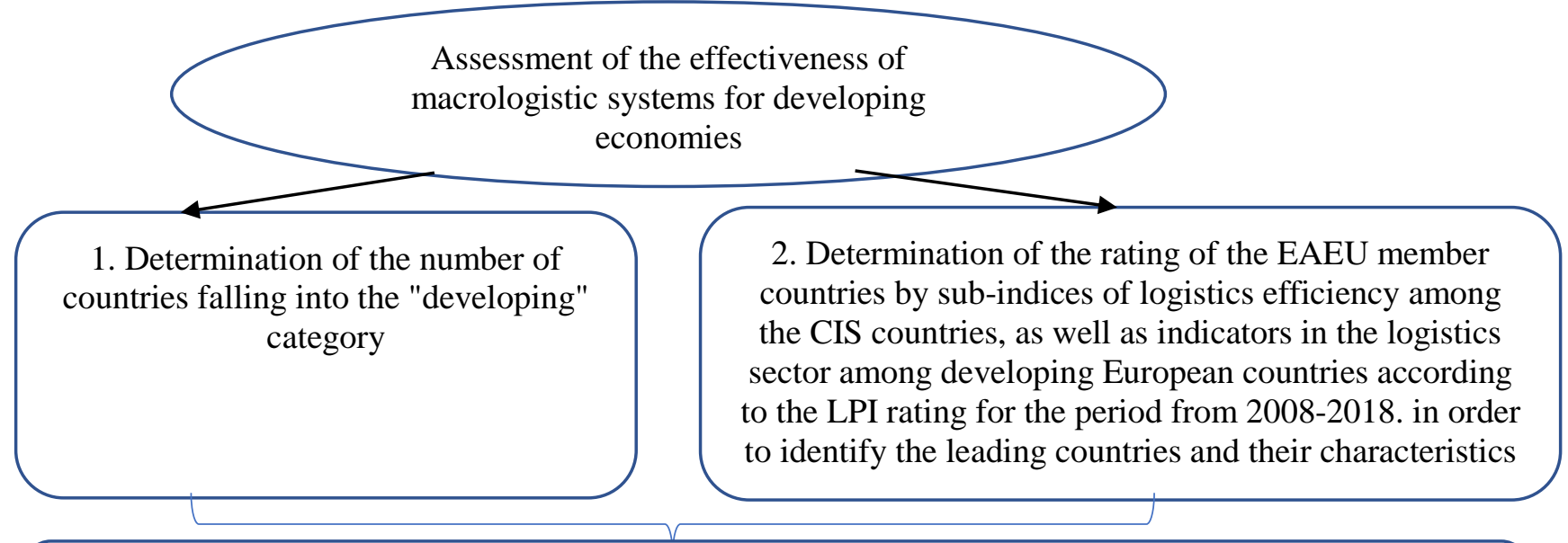

3. Identification of seasonal factors affecting the dynamics of changes in the considered indicators of export and import of road freight transportation among the CIS countries for the period from 2017-2019 using an additive model

4. Present the results of trend-seasonal modeling for the indicators of export and import of road freight transport among the CIS countries for the period from 2017-2019

5. As a result of the calculations, show the predicted values of the indicators of export and import of road freight for 2021, which can be used by state and local authorities when developing strategies for the development of macrological systems in countries with developing economies for the medium term

Figure 1. Research questions Source: compiled by authors

According to the opinions of international experts, in order to identify the efficiency of logistics in developing countries at the proper level, recommendations were made, on the basis of which the author of the article reviewed the monthly indicators of exports and imports using the example of road freight transportation among 
ENTREPRENEURSHIP AND SUSTAINABILITY ISSUES

ISSN 2345-0282 (online) http://jssidoi.org/jesi/

2020 Volume 8 Number 2 (December)

http://doi.org/10.9770/jesi.2020.8.2(64)

Make your research more visible, join the Twitter account of ENTREPRENEURSHIP AND SUSTAINABILITY ISSUES: @Entrepr69728810

the CIS countries for 2017-2019. To construct predicted values of export and import indicators using the example of road freight transport among the CIS countries, it is necessary to consider a trend-seasonal model, the results of which will allow us to draw conclusions about an increase in the volume of export of road freight transport among the CIS countries and make informed and effective logistics decisions (Figure 1).

The development of logistics and its investment is carried out in various countries according to individual scenarios, adjusted for the peculiarities of national economic policy, geographic, demographic characteristics, urbanization and the level of development of the general infrastructure of specific regions. This is evidenced by the predicted values of exports and imports of road freight for 2021 among the CIS countries, the conclusions of which will make it possible to adopt an effective strategy for the development of transport logistics based on the results of trend-seasonal modeling.

\section{Methodological approach}

In accordance with the current rules and requirements of the market, companies provide complex logistics services that are most beneficial for customers. The number of logistics providers is constantly increasing, therefore, the quality of the services provided is growing at the same time.

In the logistics service, there are five approaches, which represent different levels of provision of logistics services in the enterprise (Figure 2).

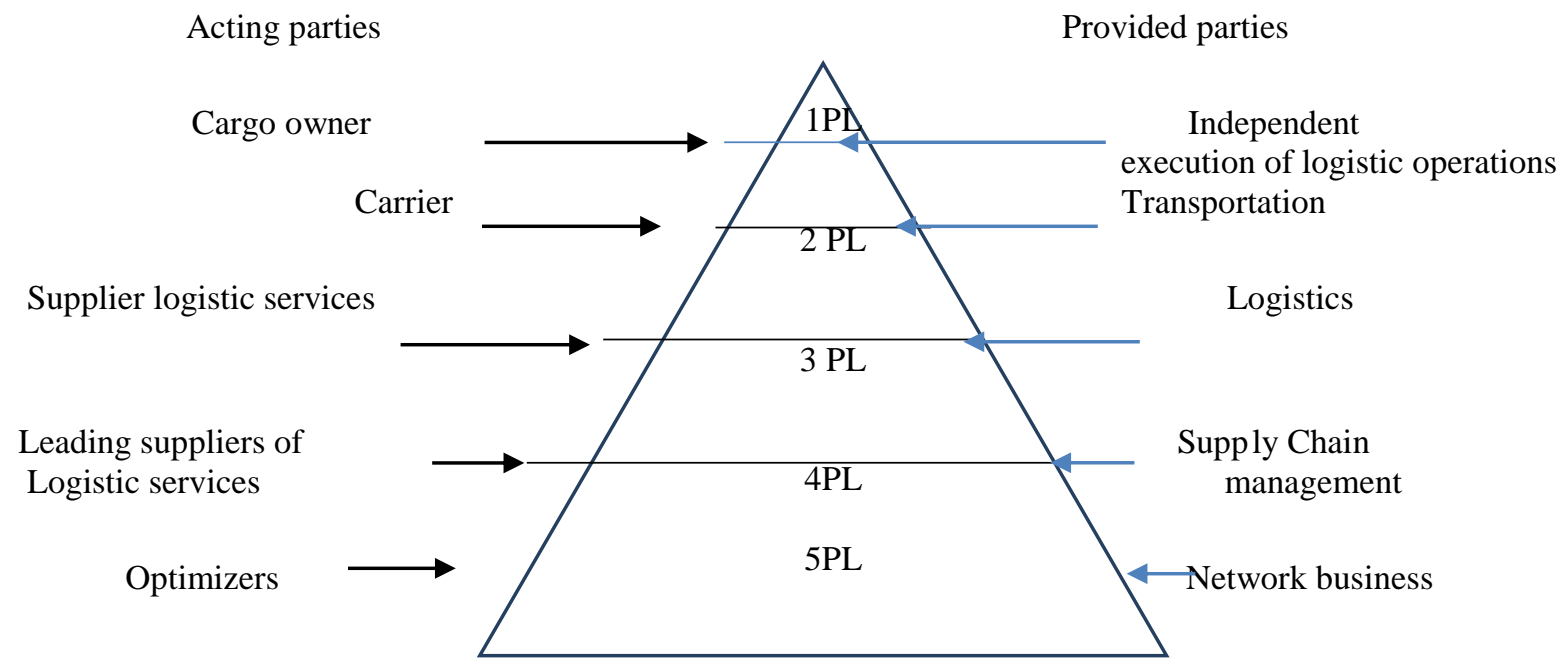

Figure 2. Concept 5- PL logistics Source: compiled by authors

As you can see from Figure 2, there are currently five logistics concepts, which are also called PartyLogistic:

1) 1PL (First Party Logistic) - Autonomous logistics. This technology was formed back in the 70s-80s of the XX century. Its peculiarity lies in the fact that the cargo owner himself performs all the logistics operations.

2) 2PL (Second Party Logistic) - Traditional logistics. This is a partial outsourcing, in which the company takes on only a part of the logistics functions, such as planning, warehousing and the formation of supply chains, resorting to using a transport company, since it does not have the necessary own transport.

3) 3PL (Third Party Logistic) - Complex logistics outsourcing. 3PL is a system when a company for the most part or completely shifts external logistics operations to another company that will deal with this. The range of 
Make your research more visible, join the Twitter account of ENTREPRENEURSHIP AND SUSTAINABILITY ISSUES: @Entrepr69728810

services of a company that deals with logistics operations includes: transportation, warehousing, packaging and forwarding of goods. 3PL is used mainly by contracting companies that provide logistics and cargo transportation services.

4) 4PL (Fourth Party Logistic) - integrated logistics outsourcing. 4PL is a service where a manufacturer engages another company that will deal with full logistics, plan and design supply chains, and also transfer to it the capabilities to manage the logistics business processes of the enterprise. 4PL is used by such companies as: Toshiba, Sony, Ford and many other major companies.

5) 5PL (Fifth Party Logistic) - "virtual logistics". When a 4PL company has an opportunity to provide network business services, it becomes a 5PL company. These companies using the global information technology space are able to provide a full range of services. Striking examples are Amazon, eBay, Aliexpress (Official site of visa and transport data, 2018).

In Western countries, a classification has long been adopted, according to which 5 levels of logistics service are distinguished. The differences between them lie in the set and features of the provision of services, the level of technologies and tools used (Table 2).

Table 2. Classification levels of logistics services

\begin{tabular}{|l|c|c|c|c|c|}
\hline \multicolumn{1}{|c|}{ Service } & 1PL & 2PL & 3PL & 4PL & 5PL \\
\hline Service planning & & & & & + \\
\hline Purchase of goods & & & & + & + \\
\hline Pick up the cargo from the supplier & & + & + & + & + \\
\hline Warehouse provision & & + & + & + & + \\
\hline Preparation of permits & & & + & + & + \\
\hline Preparation of documents for customs & & & + & + & + \\
\hline Calculation and payment of customs duties & & & + & + & + \\
\hline Passage of customs clearance of cargo & & & + & + & + \\
\hline Delivery of goods to the specified address & + & + & + & + & + \\
\hline
\end{tabular}

Source: compiled by authors

Continuous improvement of technological processes and the search for new opportunities make logistics more advanced and modern, as well as the possibility of designing and evaluating the effectiveness of a macrologistic system.

The selection is made by defining a number of criteria and their specific combination. The most demanded qualities of services in logistics companies are the following (Figure 3).

In modern conditions, the development and implementation of a strategy for the development of logistics companies using design methods and based on this forecasting methods is the most important condition for increasing the efficiency of their activities, competitiveness and sustainability in the dynamically growing economic environment of the market.

Efficient logistics can help reduce sales costs, but the weakest link in supply chains is the strength. Developing countries need to improve their infrastructure, customs system, skills and regulatory frameworks to bring logistics efficiency up to par. 


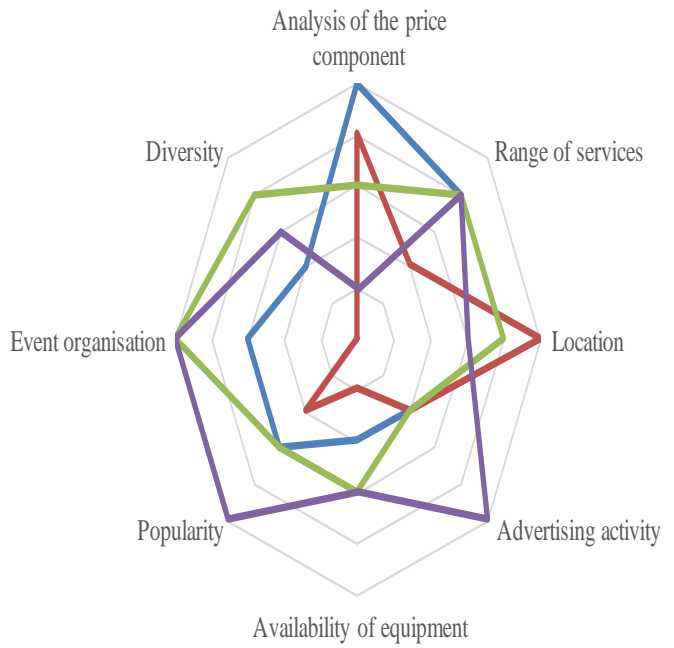

Figure 3. The most demanded quality of services of logistics companies by customers Source: compiled by authors

The efficiency of supply chains that provide access for logistics systems of developing countries to national and international markets depends on a number of factors, which, first of all, include the sustainability of supply chains, their impact on the environment and the need for skilled workers. Particular attention should be paid to the problems faced by macrological systems of countries with developing economies:

1. Both developed and developing countries face the problem of labor shortages in the field of logistics. Developing countries need more executive managers, while developed countries face labor shortages.

2. Compared to low-income countries, high-income countries are much more likely to seek to improve their cyber preparedness.

3. High-income countries are much more likely to demand environmentally friendly logistics services than lowincome countries. This is important because $\mathrm{CO} 2$ emissions from vehicles are a significant source of environmental pollution.

Thus, examining the problems faced by the macrological systems of countries with developing economies, we can say that a macrological system is a large material flow management system that functions over several enterprises or firms and unites dissimilar production and trade enterprises, transport and others to achieve a single goal of intermediary firms. A systematic and comprehensive analysis of the macrological system will allow us to trace the tendency of its change, the achievement of planned and actual results of the indicator, and also will allow us to find out the trends in the change in the cost of a unit of transport services, fulfillment of the plan by its level, and reduce costs. To determine the influence of various factors on the change in the cost of logistics services, to establish reserves and assess the work of logistics companies in using the possibilities of reducing the cost of production, visualization of the relationship of production processes aimed at increasing economic efficiency and help to optimize logistics companies.

The use of information technology in logistics allows us to solve a whole range of tasks with minimal costs, which encourages the development of information products, relying on the most unexpected and original ideas. 
ENTREPRENEURSHIP AND SUSTAINABILITY ISSUES

ISSN 2345-0282 (online) http://jssidoi.org/jesi/

2020 Volume 8 Number 2 (December)

http://doi.org/10.9770/jesi.2020.8.2(64)

Make your research more visible, join the Twitter account of ENTREPRENEURSHIP AND SUSTAINABILITY ISSUES: @Entrepr69728810

As part of modern transformations in the economic and social life of individual states, a global consumer society is being formed, in which the interests of consumers of goods and services occupy the main place in the market, where manufacturers, suppliers and sellers in such a market are obliged to satisfy the needs and requests of buyers in the shortest possible time.

Such interconnection and interaction can be achieved with the help of well-functioning logistics that ensures the efficient use of time, financial and material resources in the production and consumption of goods and services. This is evidenced by data on the number of global mergers and acquisitions in the transport and logistics industry for the period from 2013-2017, with an upward trend by 2020 (Figure 4).

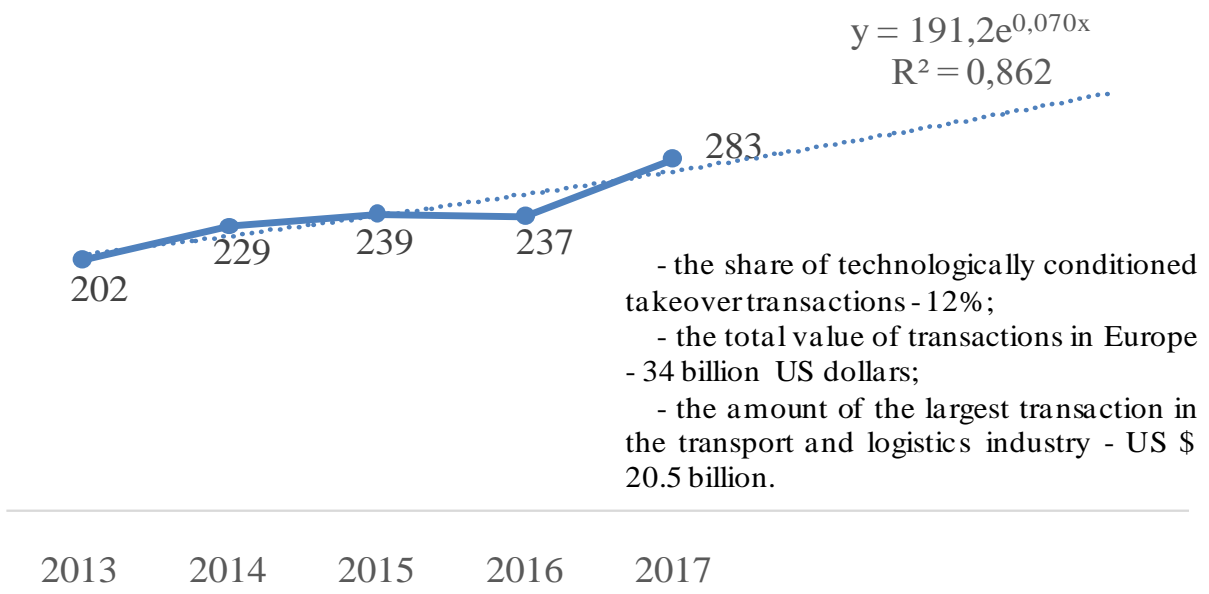

Figure 4. The number of global M\&A transactions in the transport and logistics industry for the period from 2013-2017, with an upward trend by 2020

Source: compiled by authors according to PwC Transport and Logistics Practice Report in Central and Eastern Europe

Assessing the effectiveness of macrological systems for countries with developing economies, we note that in 2020 the number of countries that fall into the category of "developing" reached 132. All of them occupy a special place in the world economy, are in different ways connected with capitalist countries, the world economic system and market. Because of this, a multi-structured economy has long been formed in such states, depending on developed and advanced countries.

But the situation that developed at the beginning of 2020, due to the pandemic, which caused negative changes in the entire global economy, led to the fact that the market of transport and logistics services is currently experiencing ups and downs: there has been an adaptation to the sanctions regime, prices for oil and the national currency rate (Bykova, Pustokhina, 2020).

To transform the market of transport and logistics services, due to its underdevelopment, mechanisms are needed to increase the competitiveness of logistics companies and maneuver in a crisis and political tension (Repnikova, Bykova, Skryabin, Morkovkin, Noval, 2019). 
Make your research more visible, join the Twitter account of ENTREPRENEURSHIP AND SUSTAINABILITY ISSUES: @Entrepr69728810

The World Bank classifies countries as developing countries with low and middle income (low and middle income). Income is measured by gross national income (GNI) per capita in US dollars. Low income is \$1.045 or less, medium income is $\$ 1.045$ to $\$ 12.746$.

The International Monetary Fund classifies countries into advanced countries and developing countries. As a criterion, the level of per capita income, export diversification, and the degree of integration into the world financial system are used.

Consider the rating of the EAEU member countries by logistics efficiency sub-indices among the CIS countries in 2008-2018, which looks like this (Table 3).

Table 3. Rating of the EAEU member countries by logistics efficiency sub-indices among the CIS countries in 2008-2018

\begin{tabular}{|c|c|c|c|c|c|c|c|}
\hline \multirow[t]{2}{*}{ Country } & \multirow[t]{2}{*}{ Year } & \multicolumn{6}{|c|}{ Subindex LPI } \\
\hline & & $\begin{array}{l}\text { Efficiency of } \\
\text { the customs } \\
\text { clearance } \\
\text { process }\end{array}$ & $\begin{array}{l}\text { Quality of trade } \\
\text { and transport } \\
\text { infrastructure }\end{array}$ & $\begin{array}{c}\text { Ease of } \\
\text { organizing } \\
\text { international } \\
\text { supply of } \\
\text { goods }\end{array}$ & $\begin{array}{l}\text { Quality of } \\
\text { logistics } \\
\text { services }\end{array}$ & Cargo tracking & $\begin{array}{c}\text { Compliance } \\
\text { with the terms } \\
\text { of delivery of } \\
\text { goods }\end{array}$ \\
\hline \multirow[t]{6}{*}{ Kazakhstan } & 2008 & 50 & 54 & 127 & 120 & 66 & 78 \\
\hline & 2010 & 79 & 57 & 29 & 73 & 85 & 86 \\
\hline & 2012 & 73 & 79 & 92 & 74 & 70 & 132 \\
\hline & 2014 & 121 & 106 & 100 & 83 & 81 & 69 \\
\hline & 2016 & 86 & 65 & 82 & 92 & 71 & 92 \\
\hline & 2018 & 65 & 81 & 84 & 90 & 83 & 50 \\
\hline \multirow[t]{6}{*}{ Belarus } & 2008 & 112 & 92 & 134 & 85 & 109 & 78 \\
\hline & 2010 & 50 & 54 & 126 & 120 & 66 & 78 \\
\hline & 2012 & 121 & 65 & 107 & 89 & 98 & 114 \\
\hline & 2014 & 87 & 86 & 91 & 116 & 113 & 93 \\
\hline & 2016 & 136 & 135 & 92 & 125 & 134 & 96 \\
\hline & 2018 & 112 & 92 & 134 & 85 & 109 & 78 \\
\hline \multirow[t]{6}{*}{ Russia } & 2008 & 121 & 65 & 107 & 89 & 98 & 114 \\
\hline & 2010 & 115 & 83 & 96 & 88 & 97 & 88 \\
\hline & 2012 & 138 & 97 & 106 & 92 & 79 & 94 \\
\hline & 2014 & 133 & 77 & 102 & 80 & 79 & 84 \\
\hline & 2016 & 141 & 94 & 115 & 72 & 90 & 87 \\
\hline & 2018 & 97 & 61 & 96 & 71 & 97 & 66 \\
\hline \multirow[t]{6}{*}{ Armenia } & 2008 & 65 & 92 & 79 & 67 & 96 & 85 \\
\hline & 2010 & 70 & 97 & 83 & 71 & 102 & 92 \\
\hline & 2012 & 73 & 104 & 89 & 74 & 109 & 94 \\
\hline & 2014 & 75 & 107 & 90 & 79 & 114 & 98 \\
\hline & 2016 & 148 & 122 & 16 & 137 & 147 & 139 \\
\hline & 2018 & 81 & 86 & 95 & 97 & 113 & 111 \\
\hline \multirow[t]{6}{*}{ Kyrgyzstan } & 2008 & 128 & 126 & 114 & 137 & 129 & 131 \\
\hline & 2010 & 139 & 135 & 118 & 145 & 135 & 141 \\
\hline & 2012 & 143 & 142 & 123 & 148 & 138 & 148 \\
\hline & 2014 & 145 & 147 & 127 & 151 & 145 & 155 \\
\hline & 2016 & 156 & 150 & 152 & 151 & 115 & 126 \\
\hline & 2018 & 155 & 103 & 138 & 114 & 99 & 106 \\
\hline
\end{tabular}

Source: compiled by authors according to the source of Eurostat statistics www.eurostatica.com

Based on the values of the LPI logistics development indicator in 2018, Kazakhstan has the most developed logistics system among the EAEU member states, and Belarus and Kyrgyzstan have the least efficient ones. 


\section{ENTREPRENEURSHIP AND SUSTAINABILITY ISSUES}

ISSN 2345-0282 (online) http://jssidoi.org/jesi/ 2020 Volume 8 Number 2 (December)

http://doi.org/10.9770/jesi.2020.8.2(64)

Make your research more visible, join the Twitter account of ENTREPRENEURSHIP AND SUSTAINABILITY ISSUES: @Entrepr69728810

According to the LPI 2018 rating, among the EAEU member states, Kazakhstan has the best indicators in the logistics sector: 84th in the subindex "ease of organizing international deliveries of goods", 83rd - tracking the passage of goods, 50th - "meeting deadlines delivery of goods".

The state of the logistics system of the Republic of Belarus is affected by insufficient investment in this sector. In order to improve the situation, a set of measures should be implemented in Belarus both in the field of improving the logistics infrastructure and searching for new approaches to management, and in the field of automation of logistics processes.

Investigating foreign indicators, Western Europe and developed Asian regions occupy a confident leadership in terms of logistics development (Official site of World Bank, 2019). Among European countries, according to the LPI 2018 ranking, indicators in the logistics sector are occupied by the following countries for the period from 2008 to 2018 (Table 4).

Table 4. Indicators in the logistics sector among developing countries of Europe according to the LPI 2018 ranking for the period from

\begin{tabular}{|c|c|c|c|c|c|c|c|c|c|c|c|c|}
\hline Country & \multicolumn{2}{|c|}{2008} & \multicolumn{2}{|c|}{2010} & \multicolumn{2}{|c|}{2012} & \multicolumn{2}{|c|}{2014} & \multicolumn{2}{|c|}{2016} & \multicolumn{2}{|c|}{2018} \\
\hline & 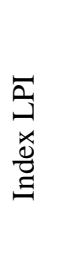 & 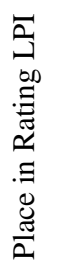 & 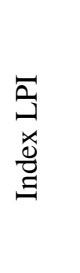 & 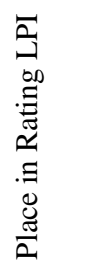 & 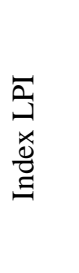 & 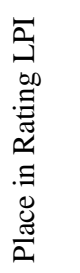 & $\begin{array}{l}\vec{a} \\
\vec{a} \\
\vec{\Xi}\end{array}$ & 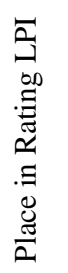 & 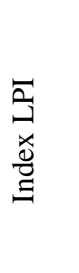 & 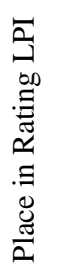 & 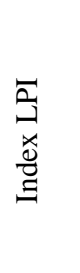 & 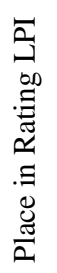 \\
\hline Poland & 3,04 & 40 & 3,44 & 30 & 3,43 & 30 & 3,49 & 31 & 3,34 & 33 & 3,54 & 28 \\
\hline Estonia & 2,95 & 47 & 3,16 & 43 & 2,86 & 65 & 3,35 & 39 & 3,36 & 38 & 3,31 & 36 \\
\hline Lithuania & 2,78 & 58 & 3,13 & 45 & 2,95 & 58 & 3,18 & 46 & 3,36 & 29 & 3,02 & 54 \\
\hline Latvia & 3,02 & 42 & 3,25 & 37 & 2,78 & 76 & 3,4 & 36 & 3,33 & 43 & 2,81 & 70 \\
\hline Moldova & 2,31 & 106 & 2,57 & 104 & 2,33 & 132 & 2,65 & 94 & 2,61 & 93 & 2,46 & 116 \\
\hline Ukraine & 2,55 & 73 & 2,57 & 102 & 2,85 & 66 & 2,98 & 61 & 2,74 & 80 & 2,83 & 66 \\
\hline
\end{tabular}

Source: compiled by authors according to the source of Eurostat statistics www.eurostatica.com

In order to bring logistics efficiency up to par, international experts recommended that developing countries improve their infrastructure, customs system, professional skills and regulatory framework. But in order to identify these criteria for the efficiency of logistics in developing countries, the author examined the monthly indicators of exports and imports using the example of road freight transportation among the CIS countries for 2017-2019 (Table 5).

Table 5. Indicators of export and import of road freight transportation of the CIS countries for 2017-2019

\begin{tabular}{|l|c|c|c|c|c|c|}
\hline \multirow{2}{*}{ Month } & \multicolumn{3}{c|}{ Export } & \multicolumn{3}{c|}{ Import } \\
\cline { 2 - 7 } & 2017 & 2018 & 2019 & 2017 & 2018 & 2019 \\
\hline \multicolumn{7}{|c|}{ Russia } \\
\hline January & 677182 & 712823 & 787786 & 698465 & 771151 & 765893 \\
\hline February & 754846 & 794575 & 887287 & 798905 & 823994 & 823599 \\
\hline March & 848981 & 893664 & 1074552 & 879366 & 905264 & 876603 \\
\hline April & 935232 & 984455 & 1040574 & 869254 & 878481 & 882853 \\
\hline
\end{tabular}

(tons) 
ENTREPRENEURSHIP AND SUSTAINABILITY ISSUES

ISSN 2345-0282 (online) http://jssidoi.org/jesi/ 2020 Volume 8 Number 2 (December)

http://doi.org/10.9770/jesi.2020.8.2(64)

Make your research more visible, join the Twitter account of ENTREPRENEURSHIP AND SUSTAINABILITY ISSUES: @Entrepr69728810

\begin{tabular}{|c|c|c|c|c|c|c|}
\hline May & 889835 & 936668 & 954788 & 901867 & 935333 & 883421 \\
\hline June & 902068 & 949545 & 843963 & 889176 & 914528 & 853635 \\
\hline July & 969837 & 1020883 & 975106 & 902004 & 902004 & 958343 \\
\hline August & 928625 & 977501 & 902890 & 898679 & 898638 & 903284 \\
\hline September & 893922 & 940971 & 908831 & 814028 & 835823 & 911075 \\
\hline October & 102403 & 1077940 & 1012707 & 916837 & 961215 & 1034072 \\
\hline November & 90720 & 954990 & 916389 & 918672 & 959392 & 964403 \\
\hline December & 828689 & 872305 & 831554 & 702498 & 723749 & 761391 \\
\hline \multicolumn{7}{|c|}{ Belarus } \\
\hline January & 354759 & 372780 & 430409 & 152987 & 165451 & 173575 \\
\hline February & 329783 & 356933 & 424799 & 167109 & 182764 & 188152 \\
\hline March & 361297 & 371639 & 459662 & 204928 & 212790 & 215343 \\
\hline April & 352966 & 374460 & 460332 & 171958 & 188559 & 212070 \\
\hline May & 404198 & 417104 & 456868 & 179287 & 188559 & 198956 \\
\hline June & 405029 & 409757 & 406469 & 182495 & 197225 & 176339 \\
\hline July & 412049 & 420178 & 467365 & 162108 & 174160 & 183435 \\
\hline August & 417398 & 426066 & 430319 & 158109 & 162898 & 164322 \\
\hline September & 406938 & 413337 & 445971 & 136287 & 148347 & 165251 \\
\hline October & 475198 & 496212 & 454563 & 171308 & 180440 & 190495 \\
\hline November & 442109 & 463088 & 408227 & 172109 & 188743 & 197823 \\
\hline December & 346938 & 367675 & 346497 & 180157 & 195177 & 193609 \\
\hline \multicolumn{7}{|c|}{ Kazakhstan } \\
\hline January & 13124 & 19327 & 33700 & 34619 & 34619 & 38515 \\
\hline February & 14946 & 19517 & 34328 & 41089 & 39458 & 55843 \\
\hline March & 15075 & 23167 & 35592 & 64835 & 55424 & 60379 \\
\hline April & 14397 & 20970 & 28439 & 58745 & 54766 & 67629 \\
\hline May & 17348 & 19343 & 28846 & 60824 & 53268 & 66612 \\
\hline June & 15627 & 17729 & 19354 & 59867 & 50870 & 51024 \\
\hline July & 15969 & 15940 & 17356 & 43494 & 43496 & 50072 \\
\hline August & 16296 & 14126 & 14258 & 41365 & 43369 & 47278 \\
\hline September & 15091 & 13093 & 13146 & 37023 & 38023 & 45151 \\
\hline October & 17492 & 21167 & 22920 & 51288 & 51288 & 54457 \\
\hline November & 18397 & 25224 & 24016 & 49329 & 46881 & 51910 \\
\hline December & 15017 & 25385 & 22185 & 39879 & 41050 & 45590 \\
\hline \multicolumn{7}{|c|}{ Ukraine } \\
\hline January & 381935 & 471895 & 467749 & 310207 & 388907 & 403005 \\
\hline February & 490144 & 491952 & 519714 & 400025 & 420173 & 462856 \\
\hline March & 493809 & 493809 & 534177 & 501521 & 466144 & 519316 \\
\hline April & 490114 & 485817 & 521443 & 401253 & 433871 & 527224 \\
\hline May & 505187 & 545811 & 586130 & 432286 & 470287 & 519728 \\
\hline June & 490183 & 518096 & 492974 & 432286 & 481190 & 479909 \\
\hline July & 485152 & 544654 & 598473 & 428725 & 493267 & 555809 \\
\hline August & 472185 & 529628 & 496320 & 438912 & 522966 & 525896 \\
\hline September & 483196 & 518973 & 534931 & 428286 & 479932 & 523935 \\
\hline October & 522048 & 552048 & 510739 & 438912 & 517078 & 562275 \\
\hline November & 491912 & 521912 & 465680 & 428041 & 67919 & 508889 \\
\hline December & 390120 & 400120 & 410424 & 400031 & 386860 & 441141 \\
\hline
\end{tabular}

According to the data presented in table 5, the situation is as follows:

1 Kazakhstan

In 2019, 634 thousand tons of cargo were transported from the European Union to Kazakhstan by road, which is $14.8 \%$ more than in 2018 . The increase in physical terms amounted to 82 thousand tons. 


\section{ENTREPRENEURSHIP AND SUSTAINABILITY ISSUES}

ISSN 2345-0282 (online) http://jssidoi.org/jesi/

2020 Volume 8 Number 2 (December)

http://doi.org/10.9770/jesi.2020.8.2(64)

Make your research more visible, join the Twitter account of ENTREPRENEURSHIP AND SUSTAINABILITY ISSUES: @Entrepr69728810

In 2019, 294 thousand tons of cargo were transported from Kazakhstan to the European Union by road, which is $24.5 \%$ more than in 2018.

2 Belarus

In 2019, 2,259.4 thousand tons of cargo were transported from the European Union to the Republic of Belarus by road, which is $3.6 \%$ more than in 2018. The increase in physical terms amounted to 77.7 thousand tons.

It should be noted that this is a significant reversal of the trend, since in 2018, compared to 2017, import road freight traffic from the EU to the Republic of Belarus decreased by $17 \%$.

In $2019,5191.5$ thousand tons of cargo were transported from Belarus to the European Union by road, which is $6.3 \%$ more than in 2018 .

In terms of countries, the largest increase in freight traffic in physical terms (tons) occurred in the direction of Lithuania, Poland and Latvia. Exports in physical terms decreased most of all to Germany.

3 Russia

In 2019, 10,610 thousand tons of cargo were transported from the European Union to the Russian Federation by road, which is $1.2 \%$ more than in 2018. The increase in physical terms amounted to 125.8 thousand tons. The positive dynamics at the end of the year was due to the growth in traffic in the second half of the year. In terms of countries, the largest increase in road transport in the Russian Federation in physical terms (tons) is noted from Poland, Finland, Italy, Hungary, Estonia. Freight traffic from Germany, the Netherlands and Romania has significantly decreased.

In 2019, 11,136.4 thousand tons of cargo were transported from Russia to the European Union by road, which practically corresponds to the level of $2018(+0.15 \%)$. As a reminder, in 2018, the positive dynamics of exports was $12 \%$ ). In terms of countries, the largest decrease in freight traffic in physical terms (tons) occurred in the direction of Hungary and Germany. Exports in physical terms increased most of all to Finland and Poland.

4 Ukraine

In 2019, 6,030 thousand tons of cargo were transported from the European Union to Ukraine by road, which is 9.3\% more than in 2018. The increase in physical terms amounted to 511 thousand tons.

The increase in imports occurred from almost all EU countries (with the exception of the UK and Croatia), but the most significant increase in road transport to Ukraine in physical terms (tons) came from Poland (+288 thousand tons).

In 2019, 6139 thousand tons of cargo were transported from Ukraine to the European Union by road, which is $1.1 \%$ more than in 2018. The positive dynamics decreased due to the reduction in traffic in the second half of the year.

In terms of countries, the largest increase in freight traffic in physical terms (tons) occurred in the direction of the Netherlands, Bulgaria, Lithuania. Exports in physical terms decreased most of all to Germany, Hungary, Romania. In the context of cargoes from Ukraine to the EU by road transport in the export cargo traffic, the largest increase in the volume of animal and vegetable fats, household goods, glass and glass products, food industry waste and animal feed. There was a decrease in the export road transport of wood and wood products, iron and steel products, aluminum and products from it, and sugar.

Graphical analysis indicates the influence of seasonal factors on the dynamics of changes in the indicators under consideration (Figure 5,6). 


\section{ENTREPRENEURSHIP AND SUSTAINABILITY ISSUES}

ISSN 2345-0282 (online) http://jssidoi.org/jesi/

2020 Volume 8 Number 2 (December)

http://doi.org/10.9770/jesi.2020.8.2(64)

Make your research more visible, join the Twitter account of ENTREPRENEURSHIP AND SUSTAINABILITY ISSUES: @Entrepr69728810

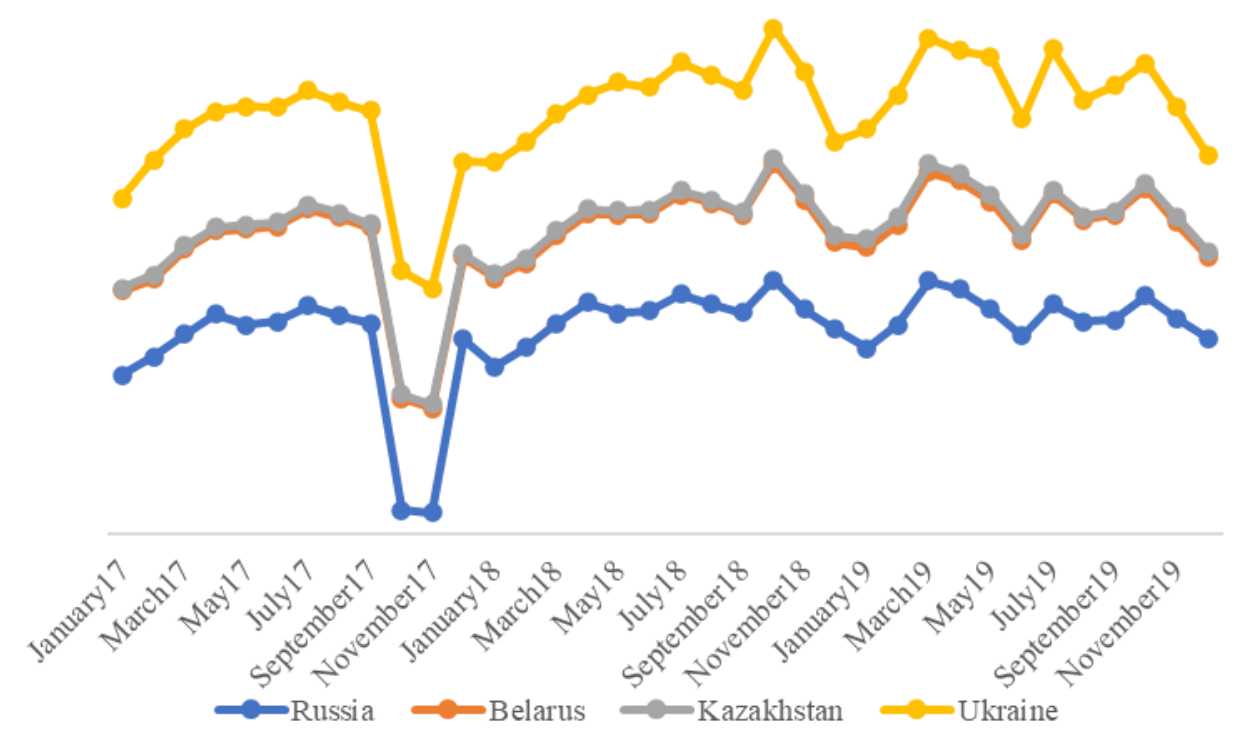

Figure 5. Dynamics of the export of road freight for 2017-2019 among the CIS countries, in tons

Source: compiled by authors according to www.eurostatica.com
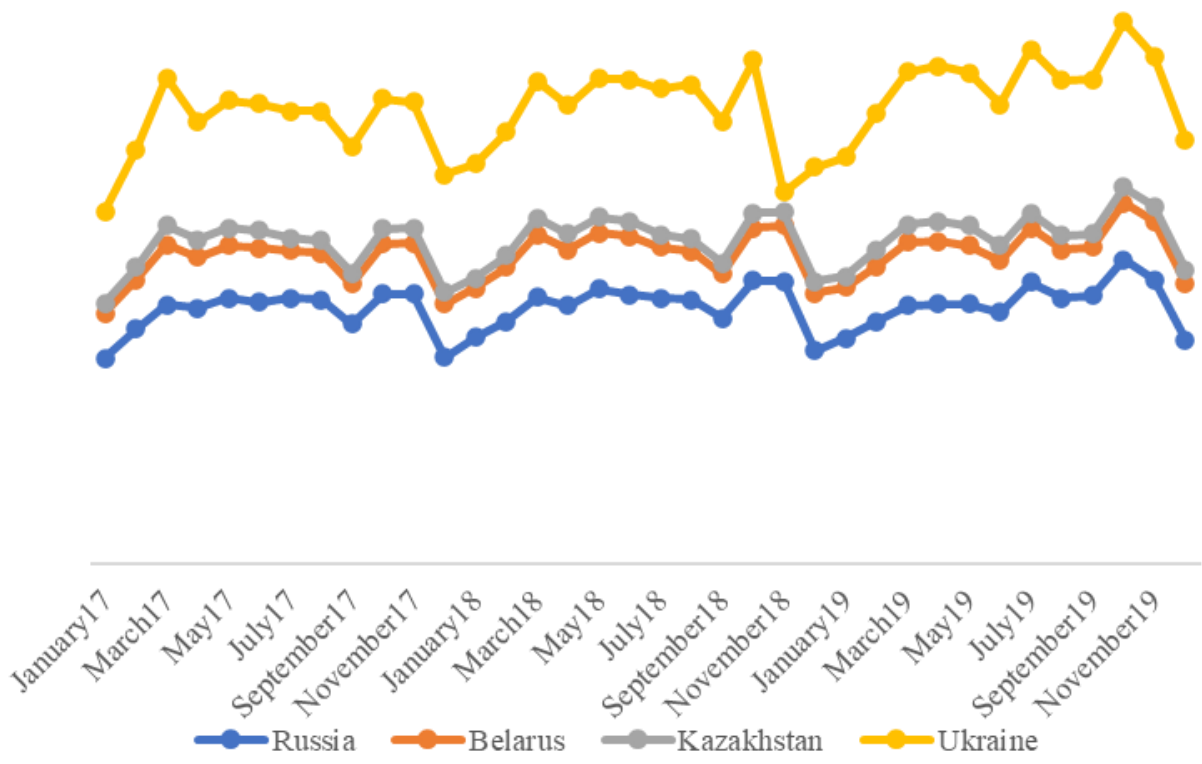

Figure 6. Dynamics of imports of road freight for 2017-2019 among the CIS countries, in tons

Source: compiled by authors according to Eurostat statistics www.eurostatica.com 


\section{ENTREPRENEURSHIP AND SUSTAINABILITY ISSUES}

ISSN 2345-0282 (online) http://jssidoi.org/jesi/ 2020 Volume 8 Number 2 (December)

http://doi.org/10.9770/jesi.2020.8.2(64)

Make your research more visible, join the Twitter account of ENTREPRENEURSHIP AND SUSTAINABILITY ISSUES: @Entrepr69728810

\section{Analysis and application functionality}

As a result, to construct a forecast, it is advisable to use trend-seasonal models. The amplitude of seasonal fluctuations in our case is constant, therefore an additive model was used for the forecast, which is built by adding the components.

In our case, the equation of the time series, taking into account seasonal fluctuations, is represented by the formula:

$$
Y=T+S+E \text {, }
$$

Where:

$Y$ - time series level,

$T$ - trend component,

$S$ - seasonal component,

$E$ - random component.

The construction of an additive model is reduced to calculating the values of T, S and E based on actual indicators for the previous period, namely, monthly indicators of the volume of exports and imports of road freight for 20172019.

The forecasting process includes the following steps:

1) Aligning the original series using the moving average method.

2) Calculation of the values of the seasonal component $S$.

3) Elimination of the seasonal component $\mathrm{S}$ from the initial levels of the series and obtaining the aligned data $(\mathrm{T}+$ E).

4) Analytical alignment of levels $(T+E)$ and calculation of $T$ values using the obtained linear trend equation.

5) Estimation of the absolute error to determine the degree of conformity of the model to the original data.

6) Building a forecast based on seasonal fluctuations (Hayaloglu, 2015).

The results of trend-seasonal modeling for the considered indicators are presented in Table 6.

The forecast values of the volumes of exports and imports of road freight transportation for 2021 are determined as the sum of the trend $\mathrm{T}$ and the corresponding seasonal $\mathrm{S}$ component (Table 7).

Table 6. Results of trend-seasonal modeling for the indicators of export and import of road freight transportation

\begin{tabular}{|c|c|c|c|c|c|}
\hline Index & Trending component & \multicolumn{4}{|c|}{ Monthly seasonal components } \\
\hline \multicolumn{6}{|c|}{ Russia } \\
\hline \multirow{3}{*}{ Export } & \multirow{3}{*}{$T=873948,10+2028,62 t$} & $S_{1}=-181395,25$ & $S_{2}=-90342,37$ & $\mathrm{~S}_{3}=53060,17$ & $\mathrm{~S}_{4}=81391,96$ \\
\hline & & $\mathrm{S}_{5}=14649,92$ & $\mathrm{~S}_{6}=-34575,20$ & $\mathrm{~S}_{7}=85666,02$ & $\mathrm{~S}_{8}=38305,59$ \\
\hline & & $S_{9}=-4769,50$ & $S_{10}=121874,98$ & $S_{11}=-1562,83$ & $S_{12}=-82303,50$ \\
\hline Absolute error & $\mathrm{R}^{2}=0,81$ & Model explains & $1 \%$ of total time & ries variation & \\
\hline \multirow{3}{*}{ Import } & \multirow{3}{*}{$T=838923,02+1676,68 t$} & $\mathrm{~S}_{1}=-92898,63$ & $\mathrm{~S}_{2}=-38893,80$ & $\mathrm{~S}_{3}=26125,45$ & $\mathrm{~S}_{4}=11394,74$ \\
\hline & & $\mathrm{S}_{5}=36709,62$ & $S_{6}=9234,45$ & $\mathrm{~S}_{7}=42392,81$ & $\mathrm{~S}_{8}=37128,10$ \\
\hline & & $S_{9}=-37061,80$ & $S_{10}=76812,95$ & $S_{11}=76919,93$ & $S_{12}=-147863,84$ \\
\hline Absolute error & $\mathrm{R}^{2}=0,89$ & \multicolumn{4}{|c|}{ Model explains $89 \%$ of total time series variation } \\
\hline \multicolumn{6}{|c|}{ Belarus } \\
\hline \multirow{3}{*}{ Export } & \multirow{3}{*}{$T=381586,28+1579,98 t$} & $S_{1}=-19666,90$ & $S_{2}=-31817,00$ & $\mathrm{~S}_{3}=-8114,88$ & $S_{4}=-6752,67$ \\
\hline & & $\mathrm{S}_{5}=13973,10$ & $\mathrm{~S}_{6}=-14184,84$ & $\mathrm{~S}_{7}=12366,27$ & $\mathrm{~S}_{8}=14429,23$ \\
\hline & & $\mathrm{S}_{9}=-1194,04$ & $S_{10}=70087,39$ & $S_{11}=33646,81$ & $S_{12}=-62772,48$ \\
\hline Absolute error & $\mathrm{R}^{2}=0,72$ & Модель объяс & ет $72 \%$ общей в & иации времен & рго ряда \\
\hline \multirow{3}{*}{ Import } & \multirow{3}{*}{$T=165602,18+783,25 t$} & $S_{1}=-11065,19$ & $S_{2}=4306,06$ & $\mathrm{~S}_{3}=32181,70$ & $\mathrm{~S}_{4}=17426,56$ \\
\hline & & $\mathrm{S}_{5}=9934,12$ & $S_{6}=2142,66$ & $\mathrm{~S}_{7}=-8025,84$ & $S_{8}=-16523,65$ \\
\hline & & $\mathrm{S}_{9}=-35365,52$ & $\mathrm{~S}_{10}=-2861,17$ & $\mathrm{~S}_{11}=445,39$ & $\mathrm{~S}_{12}=7404,87$ \\
\hline
\end{tabular}




\section{ENTREPRENEURSHIP AND SUSTAINABILITY ISSUES}

ISSN 2345-0282 (online) http://jssidoi.org/jesi/ 2020 Volume 8 Number 2 (December)

http://doi.org/10.9770/jesi.2020.8.2(64)

Make your research more visible, join the Twitter account of ENTREPRENEURSHIP AND SUSTAINABILITY ISSUES: @Entrepr69728810

\begin{tabular}{|c|c|c|c|c|c|}
\hline Absolute error & $\mathrm{R}^{2}=0,89$ & \multicolumn{4}{|c|}{ Model explains $89 \%$ of total time series variation } \\
\hline \multicolumn{6}{|c|}{ Kazakhstan } \\
\hline \multirow{3}{*}{ Export } & \multirow{3}{*}{$T=12975,40+376,57 t$} & $\mathrm{~S}_{1}=4411,98$ & $\mathrm{~S}_{2}=4834,54$ & $\mathrm{~S}_{3}=7374,52$ & $\mathrm{~S}_{4}=2626,96$ \\
\hline & & $\mathrm{S}_{5}=1786,81$ & $\mathrm{~S}_{6}=-4032,58$ & $\mathrm{~S}_{7}=-2807,54$ & $\mathrm{~S}_{8}=-4383,50$ \\
\hline & & $\mathrm{S}_{9=-6333,73}$ & $\mathrm{~S}_{10}=-1816,21$ & $\mathrm{~S}_{11}=132,71$ & $\mathrm{~S}_{12}=-1793,98$ \\
\hline Absolute error & $\mathrm{R}^{2}=0,74$ & Model explains & $4 \%$ of total time & ries variation & \\
\hline \multirow{3}{*}{ Import } & \multirow{3}{*}{$T=45808,82+180,50 t$} & $\mathrm{~S}_{1}=-11397,34$ & $\mathrm{~S}_{2}=-574,07$ & $\mathrm{~S}_{3}=9384,41$ & $\mathrm{~S}_{4}=12445,06$ \\
\hline & & $\mathrm{S}_{5}=11067,77$ & $\mathrm{~S}_{6}=1902,02$ & $\mathrm{~S}_{7}=-3579,17$ & $\mathrm{~S}_{8}=-5095,71$ \\
\hline & & $\mathrm{S}_{9}=-10154,26$ & $\mathrm{~S}_{10}=3518,49$ & $\mathrm{~S}_{11}=29,83$ & $S_{12}=-7547,03$ \\
\hline Absolute error & $\mathrm{R}^{2}=0,82$ & \multicolumn{4}{|c|}{ Model explains $82 \%$ of total time series variation } \\
\hline \multicolumn{6}{|c|}{ Ukraine } \\
\hline \multirow{3}{*}{ Export } & \multirow{3}{*}{$T=471008,39+1431,16 t$} & $\mathrm{~S}_{1}=-33650,42$ & $\mathrm{~S}_{2}=-503,09$ & $\mathrm{~S}_{3}=6076,29$ & $\mathrm{~S}_{4}=-5128,92$ \\
\hline & & $\mathrm{S}_{5}=57993,69$ & $\mathrm{~S}_{6}=-2318,31$ & $\mathrm{~S}_{7}=23287,60$ & $\mathrm{~S}_{8}=6887,27$ \\
\hline & & $\mathrm{S}_{9}=5608,23$ & $\mathrm{~S}_{10}=40078,04$ & $\mathrm{~S}_{11}=7603,04$ & $S_{12}=-105933,42$ \\
\hline Absolute error & $\mathrm{R}^{2}=0,75$ & Model explains & $5 \%$ of total time & ries variation & \\
\hline \multirow{3}{*}{ Import } & \multirow{3}{*}{$T=399296,97+3367,69 t$} & $\mathrm{~S}_{1}=-63881,43$ & $S_{2}=-22782,68$ & $\mathrm{~S}_{3}=24627,97$ & $\mathrm{~S}_{4}=7882,72$ \\
\hline & & $\mathrm{S}_{5}=18088,32$ & $\mathrm{~S}_{6}=1089,53$ & $\mathrm{~S}_{7}=19975,36$ & $\mathrm{~S}_{8}=36676,09$ \\
\hline & & $\mathrm{S}_{9}=8166,39$ & $\mathrm{~S}_{10}=29057,26$ & $\mathrm{~S}_{11}=3852,66$ & $S_{12}=-62752,20$ \\
\hline Absolute error & $\mathrm{R}^{2}=0,86$ & Model explai & $6 \%$ of total time & ries variation & \\
\hline
\end{tabular}

Source: compiled and calculated by authors

Table 7. Forecasted values of export and import indicators of road freight for 2021

\begin{tabular}{|l|c|c|c|c|c|c|c|c|}
\hline \multirow{2}{*}{ Month } & \multicolumn{9}{c|}{ Export } & \multicolumn{3}{c|}{ Import } \\
\cline { 2 - 9 } & Russia & Belarus & Kazakhstan & Ukraine & Russia & Belarus & Kazakhstan & Ukraine \\
\hline January & 791955,35 & 439338,35 & 35839,08 & 507484,77 & 828181,52 & 192916,38 & 43255,87 & 500432,53 \\
\hline February & 885036,85 & 428768,22 & 36638,21 & 542063,27 & 883863,03 & 209070,88 & 54259,63 & 544898,98 \\
\hline March & 1030468,01 & 454050,33 & 39554,76 & 550073,80 & 950558,95 & 237729,78 & 64398,61 & 595677,31 \\
\hline April & 1060828,43 & 456992,51 & 35183,76 & 540299,75 & 937504,92 & 223757,89 & 67639,75 & 582299,76 \\
\hline May & 996115,01 & 479298,26 & 34720,18 & 604853,51 & 964496,47 & 217048,70 & 66442,96 & 595873,06 \\
\hline June & 948918,50 & 452720,30 & 29277,35 & 545972,67 & 938697,98 & 210040,50 & 57457,71 & 582241,96 \\
\hline July & 1071188,36 & 480851,39 & 30878,95 & 573009,75 & 973533,01 & 200655,25 & 52157,02 & 604495,48 \\
\hline August & 1025856,54 & 484494,32 & 29679,56 & 558040,58 & 969944,98 & 192940,69 & 50820,97 & 624563,91 \\
\hline September & 984810,08 & 470451,03 & 28105,90 & 558192,69 & 897431,76 & 174882,07 & 45942,93 & 599421,89 \\
\hline October & 1113483,18 & 543312,45 & 32999,98 & 594093,67 & 1012983,19 & 208169,68 & 59796,18 & 623680,46 \\
\hline November & 992073,99 & 508451,84 & 35325,47 & 563049,82 & 1014766,84 & 212259,49 & 56488,01 & 601843,55 \\
\hline December & 913361,95 & 413612,53 & 33775,34 & 450944,53 & 791659,75 & 220002,22 & 49091,65 & 538606,39 \\
\hline
\end{tabular}

Source: compiled and calculated by authors

Graphically, the forecasted values of the indicators of export and import of road cargo transportation for 2021 among the CIS countries are as follows (Figure 7,8). 
ENTREPRENEURSHIP AND SUSTAINABILITY ISSUES

ISSN 2345-0282 (online) http://jssidoi.org/jesi/

2020 Volume 8 Number 2 (December)

http://doi.org/10.9770/jesi.2020.8.2(64)

Make your research more visible, join the Twitter account of ENTREPRENEURSHIP AND SUSTAINABILITY ISSUES @Entrepr69728810
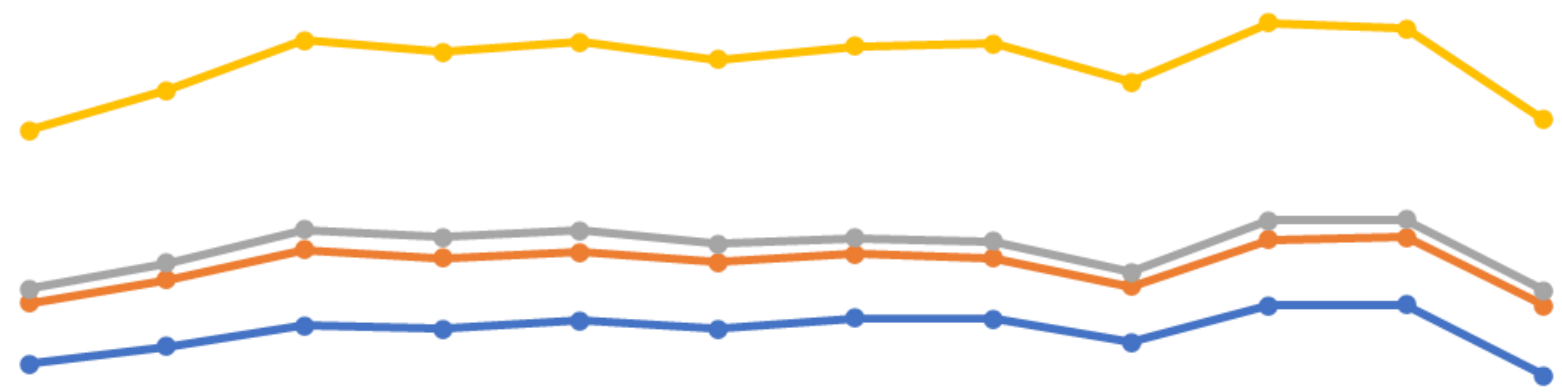

January February March April May June July August September October November December
\[ - \text { Russia }- \text { Belarus }- \text { Kazakhstan }- \text { Ukraine } \]

Figure 7. Forecasted values of indicators of imports of road freight for 2021 among the CIS countries Source: compiled and calculated by authors

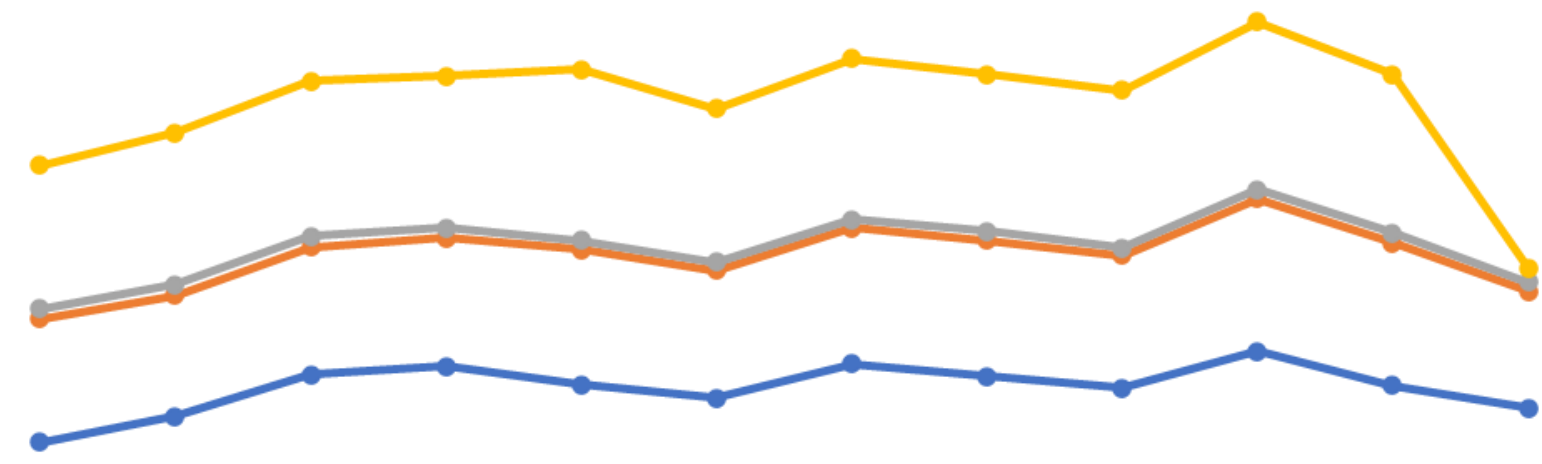

January February March April May June July August September October NovemberDecember
-Russia - Belarus - Kazakhstan $=$ Ukraine

Figure 8. Forecasted values of export indicators for road freight for 2021 among the CIS countries Source: compiled and calculated by authors 


\section{ENTREPRENEURSHIP AND SUSTAINABILITY ISSUES}

ISSN 2345-0282 (online) http://jssidoi.org/jesi/

2020 Volume 8 Number 2 (December)

http://doi.org/10.9770/jesi.2020.8.2(64)

Make your research more visible, join the Twitter account of ENTREPRENEURSHIP AND SUSTAINABILITY ISSUES: @Entrepr69728810

The obtained forecast indicators for the export and import of road freight for 2021 among the CIS countries indicate that the most stable dynamics is observed in Kazakhstan, while in other countries - Ukraine, Russia, Belarus, there is a certain decline. Although the indices of imports and exports in Kazakhstan are much lower, perhaps in other CIS countries. This allows us to draw conclusions that it is necessary to increase the volume of export of road freight in Kazakhstan.

\section{Conclusion}

The global trends of global world economic development indicate that the formation of markets for needs leads not only to the development of the market of producers. The consequence of this process, under the influence of a number of reasons and factors, is the development of logistics and logistics systems in general.

The development of logistics and its investment is carried out in various countries according to individual scenarios, as shown to us by the forecast values of exports and imports of road cargo transportation among the CIS countries, adjusted for the peculiarities of national economic policy, geographic, demographic characteristics, urbanization and the level of development of the general infrastructure of specific regions. A common feature of the logistics systems of developed European, American and Asian markets is an orientation towards modernization through the introduction of modern information technologies and an expansion of the range of IT services.

Focusing on the processes of functioning of logistics systems and supply chains of industrial enterprises, it is important to note that due to the circumstances of the development and dissemination of information technologies within the framework of the digitalization of the economy, new opportunities open up for the exchange of information between individual production, logistics and auxiliary systems and their elements, as well as produced and serviced. within the latest products and the external environment. From the standpoint of business, logistics is an integral management tool that contributes to the achievement of strategic, tactical or operational goals of its organization through effective (in terms of reducing overall costs and meeting the requirements of end users for the quality of products and services) management of material flows, service flows, and related them flows of information and finance.

Thus, in modern conditions, logistics and logistics systems are becoming important elements of the development potential of a market economy in any country, an important production segment of the economy. Logistics is more and more clearly outlining its specific role as an energetic locomotive that drives the transport conveyor for the supply of services, the transportation of goods, the organization of flows in the production of products, thereby ensuring progress towards achieving the goals of increasing the well-being of all citizens, national and economic independence.

Summing up, it should be noted that increasing competitiveness in the transport and logistics sector is always a set of measures, including the development of the material and technical base of the transport system, and the improvement of technologies with a regulatory and legal framework, as well as the development of human potential. These areas are appropriately assessed in the annual DOMESTIC LPI survey, and deserve maximum attention and decisive action from the involved government authorities and representatives of the transport business. The information obtained as a result of the study signals the presence of certain barriers hindering the development of the country's transport and logistics complex, noted by more general trends in the World Bank's LPI-2018 report. Developing economies face a wider range of transport logistics challenges that need to be addressed. An effective tool in this regard can be the adoption of a state strategy for the development of transport logistics based on positive international experience. 


\section{ENTREPRENEURSHIP AND SUSTAINABILITY ISSUES}

ISSN 2345-0282 (online) http://jssidoi.org/jesi/

2020 Volume 8 Number 2 (December)

http://doi.org/10.9770/jesi.2020.8.2(64)

Make your research more visible, join the Twitter account of ENTREPRENEURSHIP AND SUSTAINABILITY ISSUES: @Entrepr69728810

\section{References}

Adeniran, A.O., Obembe, O.E. 2020. The significance of strategic management accounting on the performance of transport businesses in Nigeria. Insights into Regional Development, 2(3), 677-688. https://doi.org/10.9770/IRD.2020.2.3(5)

Alekseycheva, E. 2015. The main ways and factors of increasing the competitiveness of industrial enterprises in Russia. Bulletin TISBI, 2 (9), 31-38.

Anikin, B. 2016. Logistics. Moscow: INFRA-M, 368 p.

Adamczak, M., Domanski, R., Hadas, L., Cyplik, P. 2016. The integration between production-logistics system and its task environment chosen aspects. IFAC-PapersOnLine, 49(12), 656-661. https://doi.org/10.1016/j.ifacol.2016.07.771

Bykova, O., Pustokhina, I. 2020. Challenges and prospects for the development of the market of transport and logistics services. Economics, Entrepreneurship and Law, 1 (10), 63-70.

Cyplic, P., Hadas, L., Adamczak, M., Domanski, R., Kupczyk, M., Pruska, Z. 2014. Measuring the level of integration in sustainable supply chain. Proc. of the 19th World Congress the International Federation of Automatic Control. Cape Town, South Africa, 4465--4470. https://www.produccioncientificaluz.org/index.php/opcion/article/viewFile/30390/31440

Damdyn, O. 2015. Transport logistics. Young scientist, 12 (24), 117-122.

Dolgov, A. 2016. Global logistics: the problem of assessing the level of development and international comparisons. Logistics today, 5 (41), 201-210.

Dolgov, A. 2015. Stocks and logistics processes in macroeconomic processes. SPb.: Publishing house of SPbGUEF, 240 p.

Dybskaya, V. 2015. Warehousing logistics for practitioners. Moscow: Alfa-Press, 208 p.

Gabbasova, V. 2016. Logistic system. Young scientist, 15(119), 281-283

Galstyan, B. 2018. Transport logistics, its essence and tasks. Young scientist, 51 (237), 224-225.

Greenwald, D. 1973. The McGraw-Hill Dictionary of Modern Economies. A Handbook of Terms and Organizations. N.Y., 215p.

Gadzhinsky, A. 2018. Methods and models of logistics: study guide. Allowance. Yekaterinburg: UrGUPS, 166 p.

Gutthorna, J. 2018. Supply Chain Management. Moscow: INFRA-M, 670 p.

Gvilia, N., Parfenov, A., Shulzhenko, T. 2019. Management of integrated intercorporate logistics systems in the digital economy. Manager, 1(10), 40-51. https://doi.org/10.29141/2218-5003-2019-10-1-4

Hayaloglu, P. 2015. The Impact of Developments in the Logistics Sector on Economic Growth: The Case of OECD Countries. International Journal of Economics and Financial Issues, 5(2), 523-530.

Jiao, R., Zhao, G.S., Wang F. 2019. Logistics Service Standardization, Enterprise Operation Efficiency, and Economic Effects", Transformations in Business \& Economics, Vol. 18, No 3(48), 168-190.

Kurenkov, P. 2016. Private car parks and problems of railway infrastructure development. Transport Bulletin, 4 (11), 10-17.

Kayikci, Y. 2018. Sustainability impact of digitization in logistics. Procedia Manufacturing, 21 (42), 782-789.

Levkin, G. 2019. Logistics. Moscow: Direct-Media, 281 p. 


\section{ENTREPRENEURSHIP AND SUSTAINABILITY ISSUES}

ISSN 2345-0282 (online) http://jssidoi.org/jesi/

2020 Volume 8 Number 2 (December)

http://doi.org/10.9770/jesi.2020.8.2(64)

Make your research more visible, join the Twitter account of ENTREPRENEURSHIP AND SUSTAINABILITY ISSUES: @Entrepr69728810

Lukinsky, V. 2017. Models and methods of the theory of logistics. SPb.: Peter, 176 p.

Lukinskiya, V., Lukinskiya, V. Shulzhenko, T. 2017. Logistic Systems Efficiency Increase Based on the Supply Chains Integration. Procedia Engineering, 19 (178), 117-122. http://dx.doi.org/10.1016/j.proeng.2017.01.073

Mader Michelle, M., \& Suski Cássio, A. (2019). Study of the effect of the Dienitro additive on the NOx and CO emissions in buses of collective transport to Diesel S-50 EGR and S-10 with SCR and EGR systems. Management of Environmental Quality: An International Journal, 31(3), 625-644.

https://www.emerald.com/insight/content/doi/10.1108/MEQ-07-2019-0158/full/html

Mirotin, L., Levin, B. 2015. Innovative processes of logistics management in intelligent transport systems. Moscow: Educational and methodological center for education in railway transport, $499 \mathrm{p}$.

Myasnikova, L. 2016. Modern problems of logistics management. SPb.: St. Petersburg State University of Economics, 152 p.

Mortansen, O., Lemoine, O. 2008. Integration between Manufacturers and third party logistics providers? International Journal of operations and Production Management, 28(4), 331-359. https://doi.org/10.1108/01443570810861552

Official site of visa and transport data. 2018. https://visasam.ru/emigration/vybor/ razvivayushchiesya-strany.html

Official site of PwC Transport and Logistics Practice Report in Central and Eastern Europe. 2018. http://www.pwc.ru

Official site of World Bank. International logistics Performance Index. 2019. https://lpi.worldbank.org/international/global

Official site of Euro Statica. 2018. Electronic resource. http://eurostatica.com

Prokofieva, T., Lopatkin, O. 2017. Logistics of transport and distribution systems: regional aspect. M.: RKconsult, 400 p.

Rostow, W. 1960. The stages of Economic Growth. N.Y., 112 p.

Repnikova, V., Bykova, O., Skryabin, O., Morkovkin, D., Novak L. 2019. Strategic aspects of innovative development of entrepreneurial entities in modern conditions. International Journal, 4(11), 32-35.

Rivera, L., Sheffi, Y., Knoppen, D. 2016. Logistics clusters: The impact of further agglomeration, training and firm size on collaboration and value added services. International Journal of Production Economics, 96 (179), 285-294. https://doi.org/10.1016/j.ijpe.2016.05.018

Stanton, W. 1978. Fundamentais of Marketing. N.Y., 314p.

Sergeev, V., Zinina, D. 2016. Analysis of existing international approaches to assessing the effectiveness of logistics. Logistics and supply chain management, 2 (11), 4-19.

Shcherbakov, V. 2018. Basics of logistics. SPb.: Peter, 432 p.

Wong, C., Boonitt, S., Wong, C. 2011. The contingency effects of environmental uncertainty on the relationship between supply chain integration and operational performance. Journal of Operations Management, 9(6), 604-615. http://dx.doi.org/10.1016/j.jom.2011.01.003 


\section{ENTREPRENEURSHIP AND SUSTAINABILITY ISSUES}

ISSN 2345-0282 (online) http://jssidoi.org/jesi/

2020 Volume 8 Number 2 (December)

http://doi.org/10.9770/jesi.2020.8.2(64)

Make your research more visible, join the Twitter account of ENTREPRENEURSHIP AND SUSTAINABILITY ISSUES: @Entrepr69728810

Yerlan KUNYAZOV is PhD student of S. Toraighyrov Pavlodar State University, Pavlodar, Kazakhstan. Research interests: economy, ecenomic development, logistic system, investments.

ORCID ID: orcid.org/0000-0002-0504-2010

Yertargyn SHAKHMAN is Prorector of S. Toraighyrov Pavlodar State University, Pavlodar, Kazakhstan. Research interests: bank lending, monetary policy; financial support for small and medium-sized businesses, sources of financing for the innovation sector

ORCID ID: orcid.org/0000-0002-0457-2247

Saule RAKHIMOVA is Candidate of Economic Sciences, Professor of S. Toraighyrov Pavlodar State University, Pavlodar, Kazakhstan. Research interests: housing financing, development of mortgage lending, investments, banking system problems ORCID ID: orcid.org/0000-0003-0553-9606

Alma MUSSINA is Candidate of Economic Sciences, Professor of S. Toraighyrov Pavlodar State University, Pavlodar, Kazakhstan. Research interests: housing financing, development of mortgage lending, investments, banking system problems ORCID ID: orcid.org/0000-0002-3893-316X

Takhir ERNAZAROV is Professor of Karaganda Economic University of S. Toraighyrov Pavlodar State University, Pavlodar, Kazakhstan. Research interests: finance, insurance, banks.

ORCID ID: orcid.org/0000-0002-9357-0103

Copyright (C) 2020 by author(s) and VsI Entrepreneurship and Sustainability Center

This work is licensed under the Creative Commons Attribution International License (CC BY).

http://creativecommons.org/licenses/by/4.0/

c) (i) Open Access 